\title{
Competitive Analysis of Tourism Sector in Brazil and Switzerland
}

\author{
Maria Gabriela Montanari ${ }^{1}$, Janaina de Moura Engracia Giraldi ${ }^{1} \&$ Carlos Alberto Gabrielli Barreto Campello ${ }^{1}$ \\ ${ }^{1}$ School of Economics, Business Administration and Accounting at Ribeirao Preto, University of Sao Paulo, \\ Brazil \\ Correspondence: Maria Gabriela Montanari, School of Economics, Business Administration and Accounting at \\ Ribeirao Preto, University of Sao Paulo, Brazil. E-mail: mariagabrielamontanari@yahoo.com.br
}

Received: February 27, 2014

Accepted: April 16, $2014 \quad$ Online Published: May 22, 2014

doi:10.5539/ijbm.v9n6p20

URL: http://dx.doi.org/10.5539/ijbm.v9n6p20

\begin{abstract}
This study analysed the relation between the competitiveness in the touristic sector of Brazil and Switzerland and the development of both countries, comparing them using a multi-criterion analysis technique called TOPSIS. The performance of the countries was assessed based onthe similarity with an ideal solution, according to the pillars of competitiveness in tourism criteria, extracted from the accredited World Index of Competitiveness in Tourism of 2009. Results give a general and simplified view of these two countries with regard to their competitiveness in tourism, facilitating a direct comparison and showing the superiority of Switzerland in relation to Brazil. This superiority was shown in terms of countries scores and in the differences in their ranking positions, consideringdifferent applications of the TOPSIS technique. The information generated in this study can be used by the tourism sector and by governments of both countries in order to develop actions and researches in this field.
\end{abstract}

Keywords: tourism, competitiveness, TOPSIS

\section{Introduction}

In an increasingly dynamic, complex and competitive world with a constantly mutating global economy, many challenges and demands are made on each participant. This complexity is the challenging and unstable scenario in which the touristic sector is found, which is globally acknowledged as one of the largest economic sectors (Littrell et al., 2004).

This sector grows exponentially for various reasons, such as activity of globalisation, innovation, ease of communication, investments in transportation and an increased need for sharing environmental resources (Clegg et al., 2004). The strength and development of the tourism sector can be illustrated by analysing the number of international tourist arrivals (overnight visitors), which increased from 995 million in 2011 to 1.035 billion in 2012, representingan increase of 4\% (40 million tourists) from one year to the next (World Tourism Organization (UNTWO), 2013). Other important data refer to the jobs created in 2012 by tourism: 260 million, meaning 1 in 11 jobs on the planet; and the investments in the sector in the same year corresponded to $4.7 \%$ of the total of investments on the planet, adding up to 764.7 billion dollars (World Travel \& Tourism Council (WTTC), 2013).

Therefore, tourism can be seen-especially in recent times-as one of the world's leading economic sectors, representing a fundamental source of revenue, employment, exports and taxes ( $\mathrm{Su} \& \mathrm{Lin}, 2013$ ). The direct and indirect contributions of this sector in 2012 represented 9.3\% of the world's GDP, totalling 6.6304 billion dollars, an increase of $3 \%$ in relation to the previous year, greater than the growth of the global economy as a whole, which was $2.3 \%$ (WTTC, 2013).

The capacity of tourism to create jobs and revenue is linked to the fact that it encompasses a series of interconnected activities, such as transportation, accommodation, food and entertainment, among others (Ferreira, 2010). Therefore, a continually increasing number of destinations and governments have opened to tourists and invested in tourism, turning tourism into an essential activity for socio-economical progress by means of exportation revenues, job and enterprise creation and infrastructure development (UNTWO, 2013).

Switzerland was one of the first countries to invest and develop tourism as an essential industry (Tajeddini, 2010). The great importance of this sector for the nation is made evident by the intensity of tourism in the region, which is measured by the ratio between the number of tourists and the native population or between tourism 
revenue andthe population (Weiemair \& Bieger, 2005). In Brazil, because of the effort made by the federal government in partnership with the private sector, the priority given to the tourism sector and the implementation of the National Tourism Policy, tourism has been achieving ever increasing numbers in recent years (Ministry of Tourism, 2013), although there is still much to exploit and develop.

The relevance of tourism activity is also connected to its great environmental impact. Standing out among all the global environmental consequences of tourism are the change in coverage and usage of land, the usage of energy, the biotic exchange and extinction of wild species, the dispersion of diseases and the modifications in the perception and comprehension of the environment (Gossling, 2002). However, tourism can stimulate initiatives for acknowledgment, preservation and dissemination of information on historical, artistic, cultural and environmental patrimony, which have evident positive impacts on the quality of life of those residing in the spaces in question.

The sector's development can also be explained in terms of competitive advantage because,to develop itself and be considered successful in international terms, an activity sector must display some competitive advantage relative to the best competitors in the world (Porter, 1999). The advantage reached by competitiveness is one of the determinant characteristics of the tourism industry in the XXI century (Miller et al., 2008). Besides, the destination marketing has become increasingly competitive in global terms (Buhalis, 2000).

The competitiveness of tourism involves several factors, such as the natural environment (e.g., geographic location, landscapes andclimate), the artificial environment (e.g., transportation, leisure and entertainment infrastructures, retail stores and hotel networks) and the globalisation of markets (Navickasand Malakauskaite, 2009). Furthermore, the competitiveness of a tourism destination is assessed from the perspective of tourist satisfaction and sustainable development (Lee \& King, 2009).

The diversity of the industries involved in planning and developing a tourism destination requires a competitiveness model that examines the relations between the participating stakeholders to create and integrate products with great added value in order to maintain the resources while at the same time maintaining a competitive market position in relation to the other competitors (Hassan, 2000). In tourism, in addition to competing for the tourists themselves, providers compete for the use of scarce resources such as land, water, work force and energy (Tao \& Wall, 2009).

Therefore, the success of a tourism destination's (city, region or country) strategic position in the international tourism market involves a set of decisions that represents a source of competitive advantage over other competing destinations (Pike, 2008). It is thus necessary to create new strategiesto reach competitiveness in national and international terms and to improve the strategies that already exist.

In 2009, the Travel \& Tourism Competitiveness Index (TTCI) was developed by the World Economic Forum (WEF), in partnership with institutions from several countries, to guide and serve as a reference for competitiveness in the sector. This index measures factors deemed determinant for competitiveness in tourism at the global level, classifying countries according to their performance in relation to these factors (World Economic Forum (WEF), 2009).

According to the resulting indices, Brazil is ranked $5^{\text {th }}$ in the Americas, behind the following countries in increasing order: Canada, United States, Barbados and Costa Rica. Worldwide, Brazil is ranked $45^{\text {th }}$, having risen four positions since 2008, but it is still far from Switzerland, which is ranked first (WEF, 2009). This gap separating Brazil from Switzerland shows how far behind Brazil is regarding tourism, which makes a comparison between the two countries important to trace the divergences and similarities between the two. This comparisoncan be used to identify strong points and also those that must be improved in the tourism sectors of the two countriesto develop this sector on both national and international levels and thus promote greater development for both nations.

By carefully analysing each sphere and sub-sphere of the index, administrators and governors can direct the challenges of the sector's growth; the three sub-index categories that are assessed are the (A) travel and tourism ( $T$ \& T)regulatory framework; (B) T\&T business environment and infrastructure; and (C) T\&T human, cultural and natural resources. Each of these sub-indices is composed of a pillar of competitiveness in which there is a total of 14 contexts: 1). Policy rules and regulations; 2). Environmental sustainability; 3). Safety and security; 4). Health and hygiene; 5). Prioritisation of T\&T; 6). Air transport infrastructure; 7). Ground transport infrastructure; 8). Tourism infrastructure; 9). ICT infrastructure; 10). Price competitiveness in the T\&T industry; 11). Human resources; 12). Affinity for T\&T; 13). Natural resourcesand; 14). Cultural resources (WEF, 2009).

Through these criteria, the political, economical, legal, cultural and environmental realities of a country all 
contribute to form its identity and the nation's image. The main goal of the present study is to compare Brazil to Switzerland in the field of competitiveness in tourism, in which the European nation is evidently superior, to identify the needs and opportunities of Brazil's tourism industry so that its potential may be realised and its deficiencies may be addressed. Furthermore, there is the secondary goal of comparing the two countries while considering an additional factor beyond those related to tourism competitiveness, that of economical development, measured by the GDP. These discussions may yield a theoretical reflection that would stimulate future studies in the field. The conclusions obtained from this analysis allow a measure of how far the Brazilian tourism is from the Swiss.

\section{Methods}

The goal of this article was reached quantitatively using secondary data of 2009-which was a critical year for economical indices, following the North American crisis-collected from the Travel and Tourism Competitiveness Report of the World Economic Forum, which contains the TTCI and data from the site of the World Bank. From the first source, general scores and scores related to each competitiveness pillar (T\&T regulatory framework; T\&T business environment and infrastructure; and T\&T human, cultural and natural resources) were gathered for 133 countries. From the second source, the 2009 GDPs of the 133 countries for which the TTCI is available were gathered.

Using these data, a first comparison between Brazil and Switzerland was conducted on the parameter of competitiveness in the tourism sector. The technique for orderpreferencebysimilarityto ideal solution (TOPSIS) was applied with the EXCEL software program. This technique for multi-criterion decision is widely used to assess the development of alternatives through their similarity with the ideal solution, i.e., the best alternative would be that which is closest to the positive ideal solution-the one that maximises the criteria for benefits and minimises the criteria for costs-and the most distant from the ideal negative solution, which is the exact opposite of the positive (Krohling \& Souza, 2011).

In the case of the present study, because the main goal is to directly compare Brazilian and Swiss tourism, the TOPSIS method was applied to the TTCI of 2009, using as criteria the three pillars of the Index (T\& T Regulatory Framework; T\&T Business Environment and Infrastructure; andT\&T Human, Cultural and Natural Resources) and the countries for which the Index is computed as possible decision alternatives. The chosen criteria and the acceptable alternatives form the decision matrix required to apply the TOPSIS technique (Krohling \& Souza, 2011).

Later, the TOPSIS technique was applied once more, consideringthe gross domestic product (GDP; a measure of the economic development and productivity of a country) as an additional criterion for making decisions about countries, thus increasing the size of the decision matrix. The GDP was chosen because it is a measure directly connected to a country's economic development. This measure is a variable determinate by many factors such as consumption, income, investment, government spending, taxes, exports and imports (Blanchard, 2007), and these factors are relevant when you analyse an industry like tourism. Therefore, the countries were compared based not only on factors related to tourism but also on an economic criterion.

\section{Competitiveness and Competitiveness in Tourism}

Competitiveness is a multidimensional and complex concept. According toBalkyte and Tvaronaviciene (2010), this issue can be seen under the aspects of the company's competitiveness, the competitiveness of industry and national competitiveness.

Being competitive is based on the ability to generate profit for the company and more market share (Hu \& Wall, 2005). Considering a sectorial point of view, competitiveness portrays the actions of organizations to identify and combat their competition (Kotler \& Keller, 2006). It occurs among firms from a particular market segment or industry and it is characterized not only by rivalry with competitors, but it is also related to the underlying economy and to thefive competitive forces: customers, suppliers, potential entrants, substitute products and rivalry among competitors, whose collective power determines the profit prospects of the industry (Porter, 1999).

Competitiveness can still be considered in national terms, expanding the boundaries of countries and trade barriers in order to be defined as the set of institutions, policies and factors that determine the level of productivity of a country. This will set the level of prosperity and growth of this country's economy (WEF, 2013). National competitiveness is dependent on its industry's innovation capacity and it is closely related to the country productivity, which depends both on products' quality and features and on the efficiency with which they are produced (Porter, 1999). 
Many aspects should be considered when studying the tourism competitiveness, especially if it is seen through the sectorial and national perspectives. Enright and Newton (2005) state that the competitiveness of tourist destinations usually depends on factors related to the tourism market (architecture, history, people, events) and related environmental factors (labour costs, political stability, the strategy of local businesses, system education).

Hassan (2000) states that the demand orientation is a decisive factor in competition in tourism, because of the need to rapidly respond to demand changes.Moreover, the related industries should also be differentiated and must be located near tourist destinations, as this leads to competitiveness of the tourism sector (Smeral, 1998). According to Kim and Wicks (2010, p.8) "the support of suppliers adds value to natural and manmade resources by providing complementary products such as accommodation, transport, food and various industries".

To Buhalis (2000), the destinations should be analysed based on their attractions, accessibility and transport, accommodation and services activities. Moreover, a complication factor of tourism marketing is that the destinations already have a historical past, an image and a legacy that must be taken into consideration when it comes to the study of competitiveness and the development of strategies for the sector. Ritchie and Crouch (2000) define the competitiveness of tourism in terms of the ability of a nation to create added value and increase the national wealth.

Therefore, the competitiveness of tourism destinations becomes increasingly relevant to countries that intend to control a large share of the rapidly growing tourism market (Navickas \& Malakauskaite, 2009). In this sense, the World Economic Forum (WEF) in partnership with institutions from several countries, elaborated the Travel \& Tourism Competitiveness Index-TTCI, explored in this research to measure this competitiveness. It is worth noting that the conceptualization and measurement of the competitiveness of a destination have received great attention in the literature, which is due to the economic importance of the sector and increasing competition in tourism resulting from the transition from mass tourism to tourism that addresses individual tourists' attitudes and needs ( Cracolici et al., 2008)

\section{Index of Competitiveness in Tourism and General Scores of Brazil and Switzerland}

To better understand the general scores of countries for competitiveness in tourism, especially because the general score of Brazil was lower than Switzerland's, it is necessary to clarify that this score is simply the mean value of the 3 pillars of competitiveness in tourism (each of the pillars has the same weight in determining touristic competitiveness). Each of these pillars, in turn, is computed as the mean value of the competitiveness factors of which they consist, i.e., the general score is just the mean value of the 14 aforementioned competitiveness factors. In other words, each of the 14 factors contributes with the same weight to the general score of each of the 133 countries in the Index, and taking these 14 factors into account provides a broad assessment of competitiveness.

Table 1 presents Brazil's and Switzerland's scores, which vary between 0 and 7, for the 14 contexts of TTCI and their respective positions in relation to other countries in the world. Table 1 also shows each country's score for each of the touristic competitiveness pillars.

Table 1. Comparison between Brazil and Switzerland using the travel and tourism competitiveness index (TTCI) of 2009

\begin{tabular}{|c|c|c|c|c|}
\hline & \multicolumn{2}{|c|}{ Switzerland } & \multicolumn{2}{|c|}{ Brazil } \\
\hline & Rank & Score & Rank & Score \\
\hline 1.Policy rules and regulations & 18 & 5.25 & 94 & 3.97 \\
\hline 2.Environmental sustainability & 2 & 5.89 & 33 & 4.96 \\
\hline 3.Safety and security & 8 & 6.4 & 130 & 3.36 \\
\hline 4.Health and hygiene & 13 & 6.62 & 80 & 4.2 \\
\hline 5. Prioritisation of travel \& tourism & 7 & 5.88 & 84 & 4.11 \\
\hline (A) T\&T Regulatory Framework & & 6.01 & & 4.12 \\
\hline 6. Air transport infrastructure & 17 & 4.9 & 46 & 3.76 \\
\hline 7. Ground transport infrastructure & 1 & 6.58 & 110 & 2.59 \\
\hline 8.Tourism infrastructure & 7 & 6.6 & 45 & 4 \\
\hline 9.ICT infrastructure & 3 & 5.78 & 60 & 3.06 \\
\hline 10.Price competitiveness in the $\mathrm{T} \& \mathrm{~T}$ industry & 123 & 3.59 & 91 & 4.24 \\
\hline (B) T\&T Business Environment and Infrastructure & & 5.49 & & 3.53 \\
\hline
\end{tabular}




\begin{tabular}{|c|c|c|c|c|}
\hline 11. Human resources & 4 & 6.15 & 55 & 5.17 \\
\hline 12. Affinity for travel \& tourism & 34 & 5.12 & 108 & 4.41 \\
\hline 13. Natural resources & 15 & 4.88 & 2 & 6.37 \\
\hline 14. Cultural resources & 3 & 6.02 & 14 & 5.64 \\
\hline (C) T\&T Human. Cultural and Natural Resources & & 5.54 & & 5.4 \\
\hline
\end{tabular}

Source: Adapted from WEF-2009.

Careful study of this table allows the score of both countries to be computed. Averaging the 14 factors (or the three pillars) yields a general competitiveness score of 4.35 for Brazil, while Switzerland has a score of 5.68. The difference between the two countries is more than 1 point, which is a large difference on a 0 to 7 scale.

Brazil had a lower general score because it was inferior to Switzerland in nearly all 14 aspects, the exceptions being natural resources and competitive prices; therefore, when the mean value was computed, Switzerland had a greater score. In terms of the three pillars, the only one in which Brazil ranks close to Switzerland is that of human, cultural and natural resources. Therefore, it is possible to hypothesise that Switzerland is much more developed than Brazil regarding tourism.

One should note that the computation performed here for Brazil and Switzerland was conducted by the WEF for the other countries in the Index. Based on these scores for each of the pillars in each country and on their GDP values, it was possible to apply the previously mentioned method and perform relevant analyses.

\section{Application of the TOPSIS Method and Results}

The first step to apply the TOPSIS method was to create a decision matrix, which iscomposed by alternatives and criteria. The rows are the possible decision alternatives an in this case correspond to the 133 countries in the TTCI. The columns correspond to the three pillars of the Index and these are the decision criteria used to choose a country from the first column. The general scores of the countries for each pillar are the matrix data.

Then, when there is a crossing between an alternative and a criterion, it is obtained a matrix cell, which represents the performance of the alternative chosen, according to a certain criterion.For example, the score of country $k$ for the pillar T\&T Regulatory Frameworkindicates this country's performance according to this criterion (pillar). For ease of visualisation, only a small part of the decision matrix is presented in Table 2, with only four of the 133 countries in the TTCI.

Table 2. Part of the decision matrix of the TOPSIS method

\begin{tabular}{llll}
\hline Country & T\&T Regulatory Framework & T\&T Business Environment and Infrastructure & T\&T Human, Cultural and Natural Resources \\
\hline Switzerland & 6.01 & 5.49 & 5.54 \\
Austria & 5.91 & 5.22 & 5.24 \\
Germany & 5.56 & 5.44 & 5.22 \\
France & 5.67 & 5.22 & 5.13 \\
\hline
\end{tabular}

Generally, the first step after building the decision matrix is to normalize the data. However, thisdata do not need to be normalised because it consists of dimensionless values between 0 and 7. If at least one criterion in the decision matrix was given in a different unity relative to the other values in the matrix, the whole matrix must be normalised to become dimensionless, and the different criteria can be compared using TOPSIS.

Then, the effective application of the technique may begin. The classification criteria for evaluation are divided in two types: benefits and costs. The benefit criterion means that a higher value is better, and the cost criterion is the reverse. In the application of TOPSIS, the ideal positive solutions $\mathrm{A}^{+}$(benefits) were computed, as well asthe ideal negative solutions $\mathrm{A}^{-}$(costs).

In this application, the ideal positive solution consists of the highest score found in the sample of countries for each of the pillars, and the negative solution corresponds to the lowest. Mathematically, the maximum and minimum values of each pillar were taken, corresponding to $\mathrm{A}^{+}$and $\mathrm{A}^{-}$. The results are given in Table 3 . 
Table 3. Ideal solutions

\begin{tabular}{llc}
\hline Maximum & T\&T Regulatory Framework & 6.01 \\
\hline & T\&T Business Environment and Infrastructure & 5.49 \\
& T\&T Human, Cultural and Natural Resources & 5.67 \\
\hline Minimum & T\&T Regulatory Framework & 2.83 \\
& T\&T Business Environment and Infrastructure & 1.93 \\
& T\&T Human, Cultural and Natural Resources & 2.66 \\
\hline
\end{tabular}

The result of this computation was $\mathrm{A}^{+}=(6.01 ; 5.49 ; 5.67)$ and $\mathrm{A}^{-}=(2.83 ; 1.93 ; 2.66)$. Given these ideal solutions, the Euclidean distances between the solutions and each country were computed, i.e., for each $A_{\mathrm{i}}=\left(\mathrm{p}_{\mathrm{i} 1} ; \mathrm{p}_{\mathrm{i} 2} ; \mathrm{p}_{\mathrm{i} 3}\right)$ corresponding to each country, where $\mathrm{p}_{\mathrm{i} 1}, \mathrm{p}_{\mathrm{i} 2}$ and $\mathrm{p}_{\mathrm{i} 3}$ are the scores of country $i$ for the three pillars - the T\&T Regulatory Framework, T\&T Business Environment and Infrastructureand T\&T Human, Cultural and Natural Resources, in the order used throughout this article - the two Euclidean distances $\mathrm{d}^{+}$and $\mathrm{d}^{-}$were computed, corresponding to the distances from $\mathrm{A}_{\mathrm{i}}$ to $\mathrm{A}^{+}$and to $\mathrm{A}^{-}$.

It must be mentioned that when computing $\mathrm{d}^{+}$and $\mathrm{d}^{-}$, it was assumed that the weight of each criterion on the countries and the determination of competitiveness was the same; this pattern was considered to be truebecause the general score of the Index itself is just the mean value of the pillars. The values of $\mathrm{d}^{+}$and $\mathrm{d}^{-}$for each nation were used to compute the relative proximity $(M)$ for each alternative $A_{i}$ relative to the ideal positive solution $\mathrm{A}^{+}$: $\mathrm{M}=\mathrm{d}^{-} /\left(\mathrm{d}^{-}+\mathrm{d}^{+}\right)$. This relative distance, which is the final computation of the TOPSIS method, is a relative measure of which countries are closer to the ideal positive solution and, therefore, which are better choices if one considers the pillars of competitiveness in tourism as decision criteria.

The results obtained and the ten top-ranking countries given by TOPSIS are shown in Table 4, along with the scores and rankings of each country according to theTravel and Tourism Competitiveness Index.These results show that based on both the world ranking of competitiveness in tourism and the TOPSIS method, Switzerland is first in regard to tourism and competitiveness in this activity, indicating that this nation is a power in the sector. In the case of TOPSIS, this pattern occurs because Switzerland is, relative to the other countries, the one closest to the positive ideal solution (benefits), with the highest score. It must be mentioned that the TOPSIS results are similar but not identical to those of the Index, and the former results are the ones that should be taken into consideration.

Table 4. Topsis: top ten results

\begin{tabular}{lllll}
\hline Country & Topsis & Topsis Ranking & TTCI Score & Ranking of Competitiveness in Tourism \\
\hline Switzerland & 0.977213 & 1 & 5.68 & 1 \\
Austria & 0.909378 & 2 & 5.46 & 2 \\
Germany & 0.889353 & 3 & 5.41 & 3 \\
France & 0.878268 & 4 & 5.34 & 4 \\
Canada & 0.864741 & 5 & 5.32 & 5 \\
Sweden & 0.863961 & 6 & 5.28 & 7 \\
Spain & 0.855021 & 7 & 5.29 & 6 \\
Australia & 0.844962 & 8 & 5.24 & 9 \\
United Kingdom & 0.839874 & 9 & 5.24 & 11 \\
Singapore & 0.839874 & 10 & 5.22 & 10 \\
\hline
\end{tabular}

In comparison to Switzerland, Brazil does not even appear in the top ten; Brazil is at the fiftieth position, with a TOPSIS score of 0.555913 , quite low in comparison to Switzerland's score, which is very close to 1 . This differenceindicates that Switzerland is more competitive than Brazil regarding tourism and that Brazil is very far behind in this sector, requiring more investment, incentive, prioritisation and continuous improvement. Brazil's position in the competitiveness ranking was slightly higher (45), but it was possible through TOPSIS to show that the distance between the two countries measured by evaluating the tourism sector is still large.

TOPSIS was implemented a second time, considering the GDP as another variable to consider at the moment of choosing possible alternatives (countries). The GDP values were normalised to vary between the Index pillars of 0 and 7 , so that GDP became a dimensionless variable. The decision matrix thus gained one more column than 
the matrix in Table 2, in which each country's normalised GDPwas placed.

Using this new decision matrix, new positive and negative ideal solutions were computed, i.e., $\mathrm{A}^{+}$(benefits) and $\mathrm{A}^{-}$(costs), which again are just the maximal and minimal values of each criterion (pillars and GDP). In this application, the ideal positive solution was $\mathrm{A}^{+}=(6.01 ; 5.49 ; 5.67 ; 7)$, and the ideal negative solution was $\mathrm{A}^{-}=$ $(2.83 ; 1.93 ; 2.66 ; 1)$. Next, the Euclidean distances between each country and the ideal solutions were computed once more, also considering that each criterion has the same weight. These distances were later used to compute the relative proximity $(\mathrm{M})$ for each alternative (country), indicating which countries are closer to the positive ideal solution based on a score, with a higher score indicating a result closer to the ideal. The final results are summarised in Table 5.

Inspection of the table shows that when an economic criterion such as a country's productivity as measured by the GNP is taken into account, Switzerland ceases to be the first ranked in TOPSIS, falling behind the United States, Germany, Japan and France. This pattern is consistent when one observes the global landscape, given, for example, that the United States remains the greatest power in the world, competitive not only in tourism but also in many other aspects, such as productivity.

One may also consider that Germany is the top-ranking European country in terms of economy, evading the Euro crisis with minimal damage; one may also consider that Japan has grown substantially in technological and economical terms. This small drop of Switzerland to the fifth position with a much lower score of 0.490658 demonstrates that tourism not only brings a competitive advantage to a country but might also be fundamental, as is the case of Switzerland.

Table 5. Topsis: top ten results of the second application

\begin{tabular}{lllll}
\hline Country & Topsis & $\begin{array}{l}\text { Topsis } \\
\text { Ranking }\end{array}$ & TTCI Score & Ranking of Competitiveness in Tourism \\
\hline United States & 0.850872 & 1 & 5.28 & 8 \\
Germany & 0.533999 & 2 & 5.41 & 3 \\
Japan & 0.533605 & 3 & 4.91 & 25 \\
France & 0.509107 & 4 & 5.34 & 4 \\
Switzerland & 0.490658 & 5 & 5.68 & 1 \\
United Kingdom & 0.485008 & 6 & 5.22 & 11 \\
Canada & 0.477096 & 7 & 5.32 & 5 \\
Spain & 0.475771 & 8 & 5.29 & 6 \\
Austria & 0.469773 & 9 & 5.46 & 2 \\
Australia & 0.459488 & 10 & 5.24 & 9 \\
\hline
\end{tabular}

In comparison, Brazil jumped to the 35th position in this ranking with a score of 0.368614 , closing the distance to Switzerland from 50 to 30 positions. Of course, generally speaking, even when an economic productivity and development measurement criterion was used, there remained a huge gap between the two countries, and Switzerland was still the most competitive option.

This difference can be explained by the fact that Switzerland is a small but rich country with a long tradition of hosting tourists (Weiemair \& Bieger, 2005). The country is not only a destination for leisure but also a tourism destination for business, hosting many international fairs and expositions (WEF, 2009). Additionally, the nation has efficient politics and a qualified educational system, in addition to a great diversity of education and training courses in the tourism field and a wide variety of efficient means of transportation, including buses, trains, private cars, subways and airplanes (Swiss Tourism in Figures (STF), 2007).

As for Brazil, in spite of the evident development in recent years and the sector's potential, the government's policies and actions regarding tourism and its prioritisation are still recent: the first Brazilian touristic regulations appeared only in 1958, essentially connected to energy and transportation (Becker, 2001).

Transportation infrastructure remains one of Brazilian national tourism's greatest problems; along with the lack of airlines, buses and containers, there are excessive costs involved in moving products, and there are losses due to damaged cargo. These factors are compounded by the transport matrix's distortion, with the roads being overloaded by transport that is efficiently provided by trains in Europe (Ehrhart \& Palmeira, 2006). Another aspect in which Brazil loses not only to Switzerland but also to many other countries is the issue of security, always a concern for tourists (WEF, 2009).All of these factors make Switzerland's superiority increasingly 
evident.

\section{Conclusions}

Tourism is one of the most significant, dynamic and complex phenomena in the contemporary world, directly influencing the economical, social, political and environmental development of several countries and regions involved in tourism. The sector's development is large at a global level, increasing the competition in the sector, which should be analysed with attention by the governments of countries to obtain a competitive advantage in relation to other nations of the world.

In Brazil, however, the tourism sector is still incipient and has many aspects in which it could be improved, especially compared to countries such as Switzerland that are significantly developed in this sector. This difference between the two countries in terms of tourism sectors was verified by the first application of the TOPSIS techniqueby considering the three pillars of competitiveness in tourism as determinant factors when selecting a country, which ranked Switzerland first and Brazil 50 positions behind, giving it a significantly lower score. A second application of TOPSIS also demonstrated that even with the addition of another criterion (an economic factor, the GDP) to evaluate which of the two countries would be the most viable alternative, Switzerland still had a large advantage over Brazil, although the difference in the TOPSIS ranking became smaller.

Despite this lower ranking, tourism is one of the most promising sectors in Brazil and has great potential to be explored, requiring new strategies, planning and a greater number of sources of competitiveness to attract more tourists to the country and to create more revenue and jobs.

However, the scope of this work was limited to applying a quantitative technique to assess and compare the two countries, seeking solutions and strategies. Future works would require deeper analyses and reviews of the literature on tourism in bothcountries to produce more complete evaluations and more effective suggestions. Another limitation was that the study was conducted only for the year 2009. In future studies, this technique can be replicated for other years to compare the tendencies and evolutions of the two selected countries.

Therefore, despite the study's limitations, the results give a general and simplified view of both countries, facilitating a direct comparison between the two and showing the superiority of Switzerland in relation to Brazil. Such results can be used by governments, companies and those studying the tourism sector in Brazil and Switzerland to formulate actions for developing the tourism sector at national and international levels, addressing the deficiencies of both countries in this activity and causing the nations to grow economically, politically and socially.

\section{References}

Becker, B. K. (2001). Políticas e planejamento do turismo no Brasil. Caderno Virtual de Turismo, 1(1), 1-7.

Balkyte, A., \& Tvaronaviciene, M. (2010). Perception of competitiveness in the context of sustainable development: Facets of sustainable competitiveness. Journal of Business Economics and Management, 11(2), 341-365. http://dx.doi.org/10.3846/jbem.2010.17

Blanchard, O. (2007). Macroeconomia. São Paulo: Pearson Education,

Buhalis, D. (2000). Marketing the competitive destination of the future. Tourism Management, 21, 97-116. http://dx.doi.org/10.1016/S0261-5177(99)00095-3

Clegg, S. R., Hardy, C., \& Nord, W. R. (2004). Handbook de estudos organizacionais. São Paulo: Atlas.

Cracolici, M., Nijkamp, P., \& Rietveld, P. (2008). Assessment of tourism competitiveness by analysing destination efficiency. Tourism Economics, 14(2), 325-342.

Ehrhart, S., \& Palmeira, E. M. (2006). Análise do setor de transportes. Observatório de la Economía Latinoamericana, 11(71).

Enright, M., \& Newton, J. (2005). Determinants of tourism destination competitiveness in Asia Pacific: Comprehensiveness and universality. Journal of Travel Research, 43(4), 339-350. http://dx.doi.org/10.1177/0047287505274647

Ferreira, L. B. (2010). Estratégias de segmentação da hotelaria para o turismo de negócios: um estudo em São Luís (MA) (Unpublished thesis (Dissertação de Mestrado)). Universidade de São Paulo. Rretrieved from http://www.teses.usp.br/teses/disponiveis/12/12139/tde-04112010-165809/pt-br.php/

Goosling, S. (2002). Global environmental consequences of tourism. Global Environmental Change, 12(4), 283-302. http://dx.doi.org/10.1016/S0959-3780(02)00044-4 
Hassan, S. S. (2000). Determinants of market competitiveness in an environmentally sustainable tourism industry. Journal of Travel Research, 38(3), 239-245. http://dx.doi.org/10.1177/004728750003800305

Hu, W., \& Wall, G. (2005). Environmental Management, Environmental Image and the Competitive Tourist Attraction. Journal of Sustainable Tourism, 13(6), 617-635. http://dx.doi.org/10.1080/09669580508668584.

Kim, N., \& Wicks, B. E. (2010). Rethinking Tourism Cluster Development Models for Global Competitiveness. International Chrie Conerence-Refereed Track. Anais eletrônicos Scholar Works, Illinois: Champaign. Retrieved from http://scholarworks.umass.edu/refereed/CHRIE_2010/Friday/28/

Kotler, P., \& Keller, K. L. (2006). Administração de marketing (12th ed.). São Paulo: Prentice Hall.

Krohling, R. A., \& Souza, T. T. M. De. (2011). Dois Exemplos da Aplicação da Técnica TOPSIS para Tomada de Decisão. Revista de Sistemas de Informação da FSMA, 1(8), 31-35.

Lee, C. F., \& King, B. (2009). A determination of destination competitiveness for Taiwan's hot springs tourism sector using the Delphi technique. Journal of Vacation Marketing, 15(3), 243-257. http://dx.doi.org/10.1177/1356766709104270

Littrell, M. A., Paige, R. C., \& Song, K. (2004). Senior travellers: Tourism activities and shopping behaviours. Journal of of Vacation Marketing, 10(4), 348-362. http://dx.doi.org/10.1177/135676670401000406

Miller, M. M., Henthorne, T. L., \& Babu, G. P. (2008). The Competitiveness of the Cuban Tourism Industry in the Twenty-First Century: A Strategic Re-Evaluation. Journal of Travel Research, 46(3), 268-278. http://dx.doi.org/10.1177/0047287507308319

BRASIL \& Ministério do Turismo. (2013). Turismo no Brasil: 2011-2014. Brasília: Ministério do Turismo. Retrieved from http://www.dadosefatos.turismo.gov.br/export/sites/default/dadosefatos/outros_estudos/downloads_outrose studos/Turismo_no_Brasil_2011__2014_sem_margem_corte.pdf

Navickas, V., \& Malakauskaite, A. (2009). The possibilities for the identification and evaluation of Tourism Sector. Engineering Economics, 61(1), 37-44.

Pike, S. (2008). Destination Marketing: an integrated marketing communication approach. Oxford: Elsevier.

Porter, M. E. (1999). Competição: estratégias competitivas essenciais (6th ed.). Campus Rio de Janeiro.

Ritchie, J. R. B., \& Crouch, G. I. (2000). The competitive destination, a sustainable perspective. Tourism Management, 21(1), 1-7.

Smeral, E. (1998). The impact of globalization on small and medium enterprises: new challenges for tourism policy in European countries. Tourism Management, 19(4), 371-380. http://dx.doi.org/10.1016/S0261-5177(98)00036-3

Swiss Tourism in Figures (STF). (2007). Switzerland Tourism. Geneva: STF. Retrieved from http://www.swisstourfed.ch/Files/infothek/Vademecum/2007/Def\%20Version\%20englisch.pdf

$\mathrm{Su}$, Y., \& Lin, H. (2013). Analysis of international tourist arrivals worldwide: The role of world heritage sites. Tourism Management, 40, 46-58. http://dx.doi.org/10.1016/j.tourman.2013.04.005

Tajeddini, K. (2010). Effect of customer orientation and entrepreneurial orientation on innovativeness: Evidence from the hotel industry in Switzerland. Tourism Management, 31(2), 221-231.

Tao, T. C. H., \& Wall, G. (2009). Tourism as a sustainable livelihood strategy. Tourism Management, 30(1), 90-98. http://dx.doi.org/10.1016/j.tourman.2008.03.009

World Tourism Organization (UNTWO). (2013). Tourism Highlights. Retrieved from http://mkt.unwto.org/en/publication/unwto-tourism-highlights-2013-edition

Weiemair, K., \& Bieger, T. (2005). Tourism Education in Austria and Switzerland: Past problems and future challenges. Journal of Teaching in Travel and Tourism, 5(1), 39-60.

World Economic Forum (WEF). (2009). The Travel \& Tourism Competitiveness Report 2009: Managing in a Time of Turbulence. Geneva: World Economic Forum. Retrieved from http://www.weforum.org/reports/travel-tourism-competitiveness-report-2009 


\section{Copyrights}

Copyright for this article is retained by the author(s), with first publication rights granted to the journal.

This is an open-access article distributed under the terms and conditions of the Creative Commons Attribution license (http://creativecommons.org/licenses/by/3.0/). 